\title{
Derecho constitucional y derechos humanos: haciendo manejable el análisis de estereotipos ${ }^{1}$
}

\author{
Laura Clérico ${ }^{2}$ \\ “... no es tiempo de que una mujer \\ maneje colectivos" \\ “¿Cuánto tiempo más llevará?” \\ Serú Girán \\ "Hoy paso el tiempo, demoliendo hoteles" \\ Charly García
}

\section{Introducción}

El estudio de la jurisprudencia de los tribunales nacionales y cortes de protección internacional de derechos humanos arroja como resultado que la frecuencia con que los tribunales utilizan el análisis de estereotipos va en aumento. ${ }^{4}$ Estudios recientes

\footnotetext{
1 Agradezco los comentarios, las sugerencias y lectura crítica de este trabajo a Celeste Novelli, Camila Meijide, Liliana Ronconi y a Raúl Gustavo Ferreyra.

2 Abogada (UBA), LLM.y Doctora en Derecho (Univ. de Kiel), Profesora de Derecho Constitucional (UBA), Investigadora CONICET.

3 Manifestación en la prensa de un empresario del transporte de personas en Salta. Entrevista agregada a fs. 564 del Expte en el que tramitó el caso, CSJN, Sisnero, Mirtha Graciela y otros c/Tadelva SRL y otros s/amparo (2014), Se puede consultar también en:

4 Fernández Valle, Mariano, “Apróximación a las temáticas de género en la jurisprudencia interamericana", RATJ, vol.17, 2016, en: http://www.utdt.edu/ver_contenido. php?id_contenido=12835\&id_item_menu=5858 (última consulta, 21/11/2017); Clérico, Laura: Novelli, Celeste; "La violencia contra las mujeres en las producciones de la Comisión y la Corte Interamericana de Derechos Humanos", en: Revista Estudios Constitucionales, U. de Talca, Chile (2014); Clérico, Laura; Novelli, Celeste, "La inclusión de la cuestión social en la perspectiva de género: notas para re-escribir el caso "Campo Algodonero" sobre violencia de género", en: Revista de Ciencias Sociales, Valparaíso, 2016, pp. 453-487; Clérico,
} 
demuestran esta tendencia en la jurisprudencia de la Corte IDH. Lo ha utilizado en casos sobre discriminación por orientación sexual (Atala, ${ }^{5}$ Duque, ${ }^{6}$ Flor Freire ${ }^{7}$ ), por género (Campo Algodonero, ${ }^{8}$ Atala; Artavia Murillo; ${ }^{9}$ Véliz Franco; ${ }^{10}$ Velásquez Pais; ${ }^{11}$ Gutiérrez Hernández ${ }^{12}$ ), por informalidad de la relación afectiva y familia no-tradicional (Fornerón ${ }^{13}$ ), o por discriminación interseccional, en el caso de una niña (edad y género) con VIH/SIDA (condición de persona con VIH), y viviendo en condición de pobreza (Gómez Lluy ${ }^{14}$ ), entre otros.

Sin embargo, cuanto más visible se hace la referencia a los estereotipos en la jurisprudencia, tanto más urgente se vuelve su enseñanza en la formación de grado y en las capacitaciones de operadores jurídicos. ${ }^{15} \mathrm{El}$ análisis de estereotipos no ocupa

Laura, "Impacto del caso Atala: posibilidades y perspectivas", en: V. Bogdandy/Pióvesan/ Morales (coords.), Igualdad y orientación sexual. El caso Atala de la Corte Interamericana de Derechos Humanos y su potencial, Ed. Porrúa, México, 2012, pp. 27-55.

5 Corte IDH. Caso Atala Riffo y niñas vs. Chile, Sentencia de 24 de febrero de 2012.

6 Corte IDH, Caso Duque vs. Colombia, Sentencia de 26 de febrero de 2016.

7 Corte IDH, Caso Flor Freire vs. Ecuador, Sentencia de 31 de agosto de 2016.

8 Corte IDH. Caso González y otras (“Campo Algodonero") vs. México. Sentencia de 16 de noviembre de 2009.

9 Corte IDH. Caso Artavia Murillo y otros ("Fecundación in vitro") vs. Costa Rica. Sentencia de 28 de noviembre de 2012.

10 Corte IDH, Caso Véliz Franco vs. Guatemala, Sentencia de 19 de mayo de 2014.

11 Corte IDH, Caso Velásquez Paíz vs. Guatemala, Sentencia de 19 de noviembre de 2015.

12 Corte IDH, Caso Gutiérrez Hernández vs. Guatemala, Sentencia de 24 de agosto de 2017.

13 Corte IDH, Caso Fornerón e hija vs. Argentina, Sentencia de 27 de abril de 2012.

14 Corte IDH, Caso "Gómez Lluy vs. Ecuador, Sentencia de 1 de septiembre de 2015. V. Ronconi, Liliana, "Mucho ruido y pocos... DESC. Análisis del caso Gonzales Lluy y Otros contra Ecuador de la Corte Interamericana de Derechos Humanos". en: Anuario de Derechos Humanos, 2016, 12, pp. 119-131.

15 Sobre formación en derecho y género, v. Ronconi, Liliana; Vita, Leticia, "La perspectiva de género en la formación de jueces y juezas." en: Academia. Revista sobre Enseñanza del Derecho, 2013, 11, 115-155; González, Manuela; Salanueva, Olga, “Las mujeres y el acceso a la justicia", en Derecho y Ciencias Sociales, № 6, 2012; Bergallo, Paola, "El género ausente y la enseñanza del derecho en Buenos Aires", en Rodríguez, Marcela y Asensio, Raquel, Una agenda para la equidad de género en el sistema de justicia, Buenos Aires, Del Puerto, CIEPP, 
aun un lugar preponderante en esas formaciones. Sin embargo, es urgente. Además, no hay excusas: "es una técnica que se aprende y no es difícil"16 de aplicar.

En un informe temático reciente, la $\mathrm{CIDH}$ enfatiza que tanto ella como la Corte IDH "en diversas decisiones, ... han reconocido explícitamente la necesidad de restructurar los estereotipos sociales de género y adoptar programas de educación y capacitación con una perspectiva de género, así como reformas legislativas e institucionales, con un enfoque transformador. La lista de decisiones que recopila no es menor. ${ }^{17}$ Sin embargo,

2008; Ronconi, Liliana; Vita, Leticia, “El principio de igualdad en la enseñanza del Derecho Constitucional", Academia. Revista sobre enseñanza del Derecho, año 10, № 19, 2012; Gómez del Río, María Eugenia y Ríos, Graciela, “Duración de los estudios universitarios en la carrera de Abogacía y diferencias de género", en Academia. Revista sobre enseñanza del Derecho, año 7, Nº14, 2009, pp. 119-131, entre otros.

Corte IDH. Caso González y otras ("Campo Algodonero") vs. México. Sentencia de 16 de noviembre de 2009.

16 Undurraga, Verónica, “iCuidado! Los estereotipos engañan ly pueden provocar injusticias)", en: Revista Corte Suprema, Chile, 1.03.2017, en: http://www.uai.cl/columnasde-opinion/cuidado-los-estereotipos-enganan-y-pueden-provocar-injusticias

17 CIDH, Las mujeres indígenas y sus derechos humanos en las Américas, 2017, párr. 75, con cita de: "Corte IDH. Caso González y otras ("Campo Algodonero") vs. México, Excepción Preliminar, Fondo, Reparaciones y Costas. Sentencia de 16 de noviembre de 2009, Serie C No.205, párrs. 450, 502, 540; CIDH, Informe 80/11, Caso 12.626, Jessica Lenahan (González) y otros (Estados Unidos), Fondo, 21 de julio de 2011, párr. 201; CIDH, Informe 51/13, Caso 12.551, Paloma Angélica Escobar Ledezma (México), Fondo, 12 de julio de 2013, párrs. 153-154; CIDH, Informe XX/13, Caso 12.777, Claudina Velásquez Paiz (Guatemala), Fondo, noviembre de 2013, recomendaciones 5, 7 y 8; CIDH, Informe 67/11, Caso 11.157, Gladys Carol Espinoza González (Perú), Admisibilidad y Fondo, 31 de marzo 2011, párr. 236, recomendación 8; CIDH, Informe XX/13, Caso 12.595, Ana Teresa Yarce (Colombia), Fondo, octubre de 2013, párr. 370; Corte IDH. Caso Atala Riffo y niñas vs. Chile, Fondo, Reparaciones y Costas, Sentencia de 24 de febrero de 2012, Serie C No. 239, párrs. 267, 269, 284; Corte IDH. Caso Artavia Murillo y otros ("Fecundación in vitro") vs. Costa Rica, Excepciones Preliminares, Fondo, Reparaciones y Costas, Sentencia de 28 de noviembre de 2012, Serie C No. 257, párrs. 336, 341; Corte IDH. Caso Veliz Franco y otros vs. Guatemala. Excepciones Preliminares, Fondo, Reparaciones y Costas. Sentencia de 19 de mayo de 2014, Serie C No. 277, párrs. 264, 270; Corte IDH. Caso Fernández Ortega y otros vs. México. Excepción Preliminar, Fondo, Reparaciones y Costas. Sentencia de 30 de agosto de 2010 Serie C No. 215, párr. 308, recomendaciones 14, 19, 20; Corte IDH. Caso Rosendo Cantú y otra vs. México. Excepción Preliminar, Fondo, Reparaciones y Costas. Sentencia de 31 de agosto de 2010, Serie C No. 216, párr. 295, recomendaciones 12,17 y $18 . "$ 
aún no se ha instalado en forma sistemática la perspectiva de género en la enseñanza y menos aún el análisis de estereotipos como una de sus herramientas.

Hay que reconocer que el abordaje de estereotipos como contenido de enseñanza siempre tuvo mayor presencia en sociología jurídica o criminología o derecho penal. ${ }^{18}$ Sin embargo, no abunda en derecho constitucional ni en derechos humanos ni en asignaturas que se encargan de formar en metodologías de adjudicación de derechos, sea como fuera su nombre.

El objetivo de este artículo es explorar el análisis de estereotipos como herramienta metodológica para dar pistas a quien, por ejemplo, quiere atacar la constitucionalidad o convencionalidad de una norma o de una práctica que se sustenta en imágenes estereotipadas del papel que se le asigna a determinadas personas o grupos en la sociedad y que implica una violación de derechos. ${ }^{19}$ A su vez, está dirigido a operadores jurídicos que trabajan en la justicia y deben mantener la alerta interpretativa de no incurrir en el uso de estereotipos o que tienen la obligación de desarmar los estereotipos que se enmascaran en las formalidades de las presentaciones jurídicas o en la naturalización de los bechos del caso. ${ }^{20}$ Como en forma clara y sencilla plantea Verónica Undurraga:

18 Asensio, Raquel, y otras, Discriminación de Género en Las Decisiones Judiciales: Justicia Penal y Violencia de Género, Buenos Aires: Defensoría General de la Nación, 2010, http:// www.artemisanoticias.com.ar/images/FotosNotas/inv\%20defensoria11-10\%5B1\%5D.pdf (última consulta, 11/11/2017); Freedman, Diego; González, Mariela; Kierszenbaum, Mariano; Terragni, Martiniano, “El estereotipo del joven delincuente en la última década a través de la jurisprudencia, en: Beloff, Mary; dir., Estudios sobre edad penal y derechos del niño, Buenos Aires, Ad-Hoc, 2013, pp. 199-208; Cussak, Simone, “Eliminating judicial stereotyping. Equal access to justice for women in gender-based violence cases", Documento de trabajo presentado en la Oficina del Alto Comisionado de la ONU, 2014.

19 Sobre estereotipos de género como violaciones de derechos humanos, Oficina del Alto Comisionado de la ONU, Gender Stereotyping as a Human Rights Violation, 2013, accesible en: http://www.ohchr.org/SP/Issues/Women/WRGS/Pages/GenderStereotypes.aspx (último acceso, 11/11/2017).

20 Detrás del carácter urgente de la capacitación en perspectiva de género y análisis de estereotipos se encuentra la hipótesis de trabajo que plantean Liliana Ronconi y Leticia Vita, 
"Los estereotipos operan de manera inconsciente cada vez que adscribimos a una persona atributos, características o roles solo en razón de su pertenencia o supuesta pertenencia a un determinado grupo social. Reforzamos y perpetuamos estereotipos cuando los aceptamos acríticamente en lugar de cuestionarlos. Es posible evitar caer en juicios estereotipados.... Sólo un ejemplo: cuando alguien comienza una frase con "las mujeres son ..." (puede cambiar "mujeres" por "mapuche", "gay", "migrante", etc.), póngase en alerta, porque posiblemente esté operando un juicio estereotipado. Esté atento a los contextos, porque hay espacios que favorecen la acción de estereotipos. Por ejemplo, lugares muy masculinizados donde hay pocas mujeres -como nuestro Congreso o las fuerzas armadas- son un caldo de cultivo para los estereotipos de género." ${ }^{21}$

Para ejemplificar los diferentes pasos de su uso utilizaré como ejemplos casos de la Corte IDH, del TEDH y de la Corte Suprema de Justicia argentina, ${ }^{22}$ que incluyen el análisis de

cuando sostienen que existe "una relación de pertinencia entre la capacitación que reciben quienes aspiran a o que ocupan cargos de magistratura" y perfiles de juezas y jueces "que colaboren con la construcción de un modelo de sociedad igualitario". Sobre esta base, analizan la incorporación de la perspectiva de género en la formación de aspirantes a jueces/zas y jueces/zas en ejercicio. Trabajan sobre casos en los que se intentó implementar capacitación con perspectiva de género. Identifican cómo se llevó a cabo y cuáles habrían sido las ventajas y desventajas de la modalidad concreta de intervención sobre la capacitación. Esto les permitió analiza cómo se vincula la perspectiva de género con las distintas concepciones de igualdad, por un lado, y cómo esta perspectiva es incorporada en cuatro casos de oferta de capacitación a nivel federal y provincial o local, por el otro lado. Ronconi, Liliana; Vita, Leticia, "La perspectiva de género en la formación de jueces y juezas." en: Academia. Revista sobre Enseñanza del Derecho, 2013, 11, 115-155.

21 Undurraga, Verónica, “¡Cuidado! Los estereotipos engañan (y pueden provocar injusticias)", en: Revista Corte Suprema, Chile, 1.03.2017, en: http://www.uai.cl/columnasde-opinion/cuidado-los-estereotipos-enganan-y-pueden-provocar-injusticias (última consulta 21 de noviembre de 2017), cursiva agregada.

22 Celeste Novelli me advierte sobre el potencial que tiene trabajar con casos de una Corte internacional y una Corte nacional en un mismo artículo, se lo agradezco porque cuando pensé en tomar como ejemplos casos de ambas Cortes no reflexioné sobre las razones de la selección. Novelli me explica que agregar el ida y vuelta entre, casos como Campo Algodonero de la Corte IDH y el caso Sisnero de la Corte argentina, permite mostrar el potencial que 
estereotipos de género. Sin embargo, los desarrollos que realizaremos sobre la técnica de estereotipos pueden ser utilizados para desarmar otros estereotipos, tales como por etnia, condición social, edad, religión, apariencia física, entre otros.

Con todas estas imágenes y diagnósticos sobre la formación de operadores/as jurídicos en la cabeza, pasamos al desafío de hacer el análisis de estereotipos manejable para su uso en derecho constitucional y derechos humanos. En suma, el desafío es que se instale en la caja de herramientas de uso cotidiano de los y las operadoras jurídicas. ${ }^{23}$

\section{Sobre los estereotipos}

Existen diversos ensayos sobre la definición de estereotipos. Estos desarrollos provienen de la sociología y de la psicología social. Aquí, como en tantas otras ocasiones, el derecho se presenta como un/a traductor/a. Diría como un/a traductor/a que debe ser consciente de sus limitaciones y revisar de vez en cuando lo que al respecto se produce en las disciplinas madres de esos conceptos. Esto es fundamental para que esas traducciones no queden des-actualizadas. A los efectos de este escrito, tomamos estereotipo como concepto de trabajo. Somos conscientes de que como todo concepto sus sentidos son objeto

tiene el análisis de estereotipos aun frente a hechos sustancialmente distintos (violencia de género y femicidios en Campo Algodonero, por un lado, y discriminación por género en el acceso al trabajo en Sisnero, por el otro lado). Concluye, que esto contribuye a cambiar la percepción de que la jurisprudencia internacional va por un carril y la nacional por otro, al menos esto surge de la reflexión que realiza de su experiencia personal en la cursada de varias asignaturas durante la carrera de Abogacía. Celeste Novelli, "Silencio (parcial) en la Sala. Reconstrucción crítica del enfoque de estereotipos de género en la jurisprudencia de la Corte IDH", tesis de maestría, defendida el 9 de septiembre de 2016, Univ. Nac. de San Martín/ Centro Internacional de Estudios Políticos. Las reflexiones de Celeste Novelli se podrían leer asimismo en el marco de los trabajos de Ronconi, Liliana; Vita, Leticia, “El principio de igualdad en la enseñanza del Derecho Constitucional", en Academia. Revista sobre enseñanza del derecho, 2012, Nro. 19, pp. 31-62, entre otros.

23 Horacio Mendizabal me confirma que sirve y de mucho. Lleva ya varios casos atacando la constitucionalidad de normas y prácticas basadas en estereotipos. 
de disputa. ${ }^{24}$ Sin embargo, nos sirve para identificar aspectos de violaciones a los derechos que de otro modo quedan invisibilizadas. Acudimos a la caracterización de estereotipo tal como surge de la jurisprudencia de la Corte IDH. Esta, a su vez, se inspira en las producciones de la CEDAW al respecto. ${ }^{25}$ Sin embargo, como preludio a la definición de estereotipo de la Corte IDH, que puede sonar algo técnica, sugerimos trabajar con el siguiente párrafo de Verónica Undurraga, que ha realizado una explicación del concepto de estereotipo para un público no especializado:

"Los estereotipos de género son creencias sobre los atributos de mujeres y hombres, que cubren desde rasgos de personalidad (las mujeres son más subjetivas y emocionales, los hombres son objetivos y racionales), comportamientos (las mujeres son más pasivas sexualmente, los hombres son más agresivos en ese plano), roles (las mujeres deben asumir las tareas de cuidado $y$ el hombre ser el proveedor), características físicas (las mujeres son más débiles que los hombres) y de apariencia (los hombres deben ser masculinos), ocupaciones (las carreras de armas no son para las mujeres, los bombres no pueden ser parvularios) y supuestos de orientación sexual (las lesbianas son egoístas y no priorizan el interés de sus niños; los gays son promiscuos)." 26

24 Sobre un análisis de las complejidades de los estereotipos, v. Arena, Federico. "Los estereotipos normativos en la decisión judicial. Una exploración conceptual", en Revista de derecho de la Universidad Austral de Chile, Vol. 29, № 1, 2016, pp. 51-75, quien sostiene que se suele exigir a los operadores judiciales que prevengan o contrasten los efectos perjudiciales de los estereotipos. Sin embargo, advierte que a los efectos de entender la acción requerida es necesario advertir la ambigüedad de estereotipo. Distingue así entre estereotipos descriptivos y estereotipos normativos. Por último, el trabajo propone algunos criterios de relevancia destinados a determinar cuándo el uso de estereotipos está prohibido y cuándo es obligatorio.

25 Comité CEDAW, Recomendación general No. 25, sobre el párrafo 1 del artículo 4 de la Convención sobre la eliminación de todas las formas de discriminación contra la mujer, referente a medidas especiales de carácter temporal, $30^{\circ}$ período de sesiones, 2004

26 Undurraga, Verónica, “¡Cuidado! Los estereotipos engañan ly pueden provocar injusticias)", en: Revista Corte Suprema, Chile, 1.03.2017, en: http://www.uai.cl/columnasde-opinion/cuidado-los-estereotipos-enganan-y-pueden-provocar-injusticias (última consulta 21 de noviembre de 2017), cursiva agregada. 
En Campo Algodonero, el caso de los asesinatos de mujeres en Ciudad Juárez, México, la Corte IDH aproxima una definición $^{27}$ que reitera en el reciente caso Gutiérrez Hernández c. Guatemala: ${ }^{28}$

"el estereotipo de género se refiere a una pre-concepción de atributos, conductas o características poseídas o papeles que son o deberían ser ejecutados por hombres $y$ mujeres respectivamente, y que es posible asociar la subordinación de la mujer a prácticas basadas en estereotipos de género socialmente dominantes y persistentes. En este sentido, su creación y uso se convierte en una de las causas y consecuencias de la violencia de género en contra de las mujer, condiciones que se agravan cuando se reflejan, implícita o explícitamente, en politicas $y$ prácticas, particularmente en el razonamiento y el lenguaje de las autoridades estatales ${ }^{29}$."

Por su parte, el TEDH también acude al concepto de estereotipo en su jurisprudencia. Valga como ejemplo, entre muchos otros, el caso de la Gran Sala, Konstantin Markin contra Rusia. ${ }^{30}$ En el caso, se ataca la convencionalidad de la norma que otorgaba hasta tres años de licencia parental para el cuidado de los hijos a mujeres con estado militar, pero no a varones con el mismo estado. El gobierno ruso alegó que “... la presencia y cuidado de la madre durante el primer año de la vida del niño era particularmente importante". Agregó que “... debido a que había muy pocas mujeres en el ejército, su

27 Corte IDH, Caso Campo Algodonero, párrs. 398, 401.

28 Corte IDH, Caso Gutiérrez Hernández c. Guatemala, Sentencia 24 de agosto de 2017.

29 Corte IDH, Caso Gutiérrez Hernández c. Guatemala, párr. 169, resaltado y cursiva agregada. V., Corte IDH, Caso González y otras ("Campo Algodonero") vs. México, párr. 401, y Caso Velásquez Paiz y otros Vs. Guatemala, párr. 180. Arenas, Federico, op. cit., discute la definición mixta de estereotipo usada por la Corte IDH en Campo Algodonero, en tanto combina elementos descriptivos y normativos.

30 TEDH, Konstantin Markin vs. Rusia, 22 de marzo de 2012. Sobre la sentencia de la Sala previa a la de la Gran Sala, v. Timmer, Alexandra: "From inclusion to transformation: rewriting Konstantin Markin v. Russia". En: Brems, Eva: Diversity and European Human Rights. CUP, Cambridge, 2013, p. 156. 
ausencia del servicio no tendría impacto en la capacidad de lucha”. El TEDH, con apoyo de un amicus curiae, desarma los estereotipos alegados. Por un lado, la petrificación de la imagen de las mujeres como reproductora y cuidadora como un rol natural que no es construido socialmente y que, por lo tanto, conlleva tareas que solo lo podrían realizar las mujeres. $\mathrm{Y}$, por el otro lado, el estereotipo del varón como proveedor, nacido para buscar el sustento fuera del hogar. Se trata de un asociado al uso de la fuerza física y lo militar, por oposición a los atributos asignados a los estereotipos vinculados con las mujeres: la imagen petrificada de lo delicado, de la debilidad y su falta de aptitud para actividades vinculadas al uso de la fuerza física.$^{31}$ Estas imágenes estereotipadas obturan escuchar las voces de los y las afectadas concretas, que tienen otros proyectos de vida que difieren de lo que se espera de ellas y ellos desde la automaticidad que destilan los estereotipos. "Cuando un tribunal se deja influenciar por estereotipos, juzga al individuo basado en sus ideas acerca del grupo particular y no en los hechos relevantes respecto de esa persona y las circunstancias de ese caso específico." ${ }^{22}$ No permite así que el varón se dedique al cuidado y que la mujer desarrolle su plan laboral fuera de su casa. Por todo ello, el TEDH concluye que hay discriminación de género al excluir Rusia al varón con estado militar de la posibilidad de gozar de la licencia parental para el cuidado de sus hijas e hijos.

En suma, cuando aparecen las mujeres en lugares subordinados que se refieren a los roles sociales que típicamente se le atribuyen, estamos frente a un estereotipo de género. La idea de imagen estereotipada ayuda para comprender el problema

\footnotetext{
31 V., Puga, Mariela; Otero, Romina, "Igualdad, género y acciones afirmativas. La justicia salteña y la inclusión de las mujeres en el mercado laboral”, publicado en Alegre/Gargarella (comp.), El derecho a la Igualdad, $2^{\text {a }}$ ed., Abeledo-Perrot, Buenos Aires, 2012, pp. 341-362.

32 Undurraga, Verónica, “¡Cuidado! Los estereotipos engañan ly pueden provocar injusticias)", en: Revista Corte Suprema, Chile, 1.03.2017, en: http://www.uai.cl/columnasde-opinion/cuidado-los-estereotipos-enganan-y-pueden-provocar-injusticias (última consulta 21 de noviembre de 2017), cursiva agregada.
} 
que plantea el caso y desarmar las razones que se alegan para justificar la afectación de los derechos. Esas imágenes estereotipadas refleja (y refuerzan) la distribución desigualitaria de poder que pone a un colectivo en lugar de subordinación y al otro, nuevamente por la asignación de roles sociales, en lugar de aventajado o de privilegio. ${ }^{33}$.

En este sentido, se puede pensar en dos estrategias de formación en estereotipos para operadores jurídicos. Por un lado, la discusión de algún texto de corte más teórico que trabaje estereotipos, por ejemplo, Estereotipos de género. Perspectivas legales transnacionales Rebecca Cook y Simone Cussak, ${ }^{34}$ O de acuerdo con el ciclo de enseñanza, un texto más corto y dirigido al público en general como "¡Cuidado! Los estereotipos engañan (y pueden provocar injusticias)”, de Verónica Undurraga. ${ }^{35}$ Por el otro lado, el trabajo con fallos en donde se haya realizado análisis de estereotipos. Esto conecta con el siguiente punto.

33 Aquí sigo a Iris Marion Young, (2011:69): “... la injusticia estructural existe cuando los procesos sociales sitúan a grandes grupos de personas bajo la amenaza sistemática del abuso 0 de la privación de los medios necesarios para desarrollar y ejercitar sus capacidades, al mismo tiempo que estos procesos capacitan a otros para abusar o tener un amplio espectro de oportunidades para desarrollar y ejercitar capacidades a su alcance. ... "Young, Iris, Responsability for Justice, OUP, Oxford, 2011.

34 V. Cook, Rebecca; Cusack, Simone, Estereotipos de género. Perspectivas legales transnacionales, Profamilia, Bogotá, 2010; Cardoso Onofre de Alencar, Emanuela, “Mujeres y estereotipos de género en la jurisprudencia de la Corte Interamericana de Derechos Humanos", en Eunomía. Revista en Cultura de la Legalidad No 9 (Octubre 2015 - Marzo 2016), pp. 26-48. Sobre análisis de jurisprudencia desde perspectiva de género, v. Cecilia Ezpeleta, Carmen Colazo y Laura Cantore, "Igualdad, género y constitución: aportes feministas para la reformulación del principio de igualdad. Análisis de fallos relevantes desde una perspectiva de género(s)", en Grosman, Legarre, Rivera, Elías (coord.), Tratado de Derechos Constitucionales, Abeledo Perrot/Thomson Reuters, Buenos Aires, 2014, pp. 958-1031; Díaz Alderete, Elmina Rosa, "Perspectiva de género en las sentencias judiciales y en el ámbito jurídico", LLNOA2013 (septiembre), p. 825; Deza, Soledad, "“Brujas", estereotipos de género y violencia simbólica", LLNOA2013 (agosto), p. 719.

35 Undurraga, Verónica, “¡Cuidado! Los estereotipos engañan (y pueden provocar injusticias)", en: Revista Corte Suprema, Chile, 1.03.2017, en: http://www.uai.cl/columnas-deopinion/cuidado-los-estereotipos-enganan-y-pueden-provocar-injusticias (última consulta 21 de noviembre de 2017), cursiva agregada. 


\section{Sobre el análisis de estereotipos}

El análisis de estereotipos en la jurisprudencia de la Corte IDH parece estar siempre de la mano de la desigualdad estructural. Por ejemplo, en el caso Atala v. Chile (2012) sobre discriminación por orientación sexual y género, la Corte IDH enfatiza "que algunos actos discriminatorios ... se relacionaron con la reproducción de estereotipos que están asociados a la discriminación estructural e histórica que han sufrido las minorías sexuales ..., particularmente en cuestiones relacionadas con el acceso a la justicia y la aplicación del derecho interno...”. Algo similar surge del caso paradigmático Campo Algodonero, donde la Corte IDH habla de violencia de género en un contexto de discriminación estructural contra las mujeres. Donde incluso avanza en el análisis de los estereotipos de género ${ }^{36}$ como manifestación y causal de discriminación. ${ }^{37}$ Por ejemplo, cuando identifica como la imagen estereotipada de "mujer" provoca que los agentes policiales no emprendieran acciones inmediatas para la búsqueda de las mujeres desaparecidas en Juárez. Expresaron que las mujeres eran niñas "voladas", que seguramente habrían salido con un novio y no tardarían en regresar al hogar. ${ }^{38}$ La interpretación automática de los agentes es que por ser mujeres estarían con sus novios, las mujeres estarían moldeadas para acompañar, cuando terminen esa tarea entonces volverían al hogar en donde se proyecta otra imagen: la "mujer", si joven ayuda en las tareas domésticas para cuidar a los varones de la casa; si "madre", es la encargada del cuidado de todos los integrantes del hogar. ${ }^{39}$ Así, por ejemplo, la madre de la joven Herrera sostuvo ante la Corte IDH que, al interponer

\footnotetext{
36 Corte IDH, Caso Campo Algodonero, párrs. 398, 401.

37 TIMMER, Alexandra: "Toward an Anti-Stereotyping Approach for the European Court of Human Rights". En: Human Rights Law Review, 11 (4): 707-738, 2011, además, COOK, Rebecca y CUSACK, Simone, op. cit (2010).

38 Corte IDH, Caso Campo Algodonero, párr. 198. Énfasis agregado.

39 Luego volveremos sobre "los discursos adoctrinadores" que se esconden detrás de estos tipos comentarios que buscan trasladar la responsabilidad de lo ocurrido a las víctimas.
} 
la denuncia, las autoridades le dijeron que su hija "no está desaparecida, anda con el novio o anda con los amigos de vaga" y "que si le pasaba eso era porque ella se lo buscaba, porque una niña buena, una mujer buena, está en su casa". En suma, la "mujer" aparece pensando o haciendo algo con varones. Acciona también un mecanismo de traslación de la responsabilidad, "se lo buscó", si algo le pasa. Se relaciona entonces con el papel de "mujer" sumisa y sacrificada cuya misión en la sociedad sería quedarse en el hogar para servir a los varones de la casa. Los diversos estereotipos hablan de los comportamientos esperados que las mujeres deben adoptar en el marco de sus relaciones interpersonales y en la sociedad. A su vez, usan estereotipos para las mujeres que se movilizan para reclamar, las madres o parientes de las desaparecidas. De ellas también se espera sumisión y, hasta por su condición social, se estereotipa su uso del tiempo, se la manda a tomar unas "heladas" ${ }^{40}$ Por todo ello, la Corte IDH concluye que todos estos comentarios y actitudes constituyen estereotipos. Y que "tanto las actitudes como las declaraciones de los funcionarios demuestran que existía, por lo menos, indiferencia hacia los familiares de las víctimas y sus denuncias." ${ }^{11}$ Todo esto se traduce en violaciones claras a los derechos de las mujeres desaparecidas y luego asesinadas y a sus familiares.

En el orden interno, la Corte Suprema de Justicia desmantela implícitamente estereotipos de género en el caso Sisnero sobre discriminación para el acceso de mujeres al empleo de conductoras de transporte público en la Provincia de Salta. ${ }^{42}$ La falta de

\footnotetext{
40 Sosa, Lorena, (2016). "Inter-American Court of Human Rights' case law on violence against women: breaking grounds, facing challenges", en seminario Moving beyond the good, the bad and the ugly: What to learn from International Human Rights System?, 2016, Gantes, Bélgica.

41 Corte IDH, Caso Campo Algodonero, párr. 208.

42 El caso se inicia por una acción de amparo interpuesta por Mirtha Graciela Sisnero y la Fundación Entre Mujeres (FEM) contra la Sociedad Anónima del Estado del Transporte Automotor (SAETA), la Autoridad Metropolitana de Transporte (AMI) y las siete empresas operadoras de SAETA que tienen a su cargo el transporte público de pasajeros en la ciudad de Salta. La acción contenía dos pretensiones, una individual y otra colectiva. La individual iba contra la denegatoria de las empresas de contratar a Sisnero como colectivera a pesar de
} 


\section{contratación de mujeres debía justificarse con "motivos objeti- vos y razonables". No alcanza con "dogmáticas explicaciones". La Corte no habla expresamente de imágenes estereotipadas.}

cumplir con los requisitos de idoneidad. Respecto de la pretensión colectiva, la Fundación alegó la violación de la manda de igualdad y la prohibición de no discriminación por género por la falta de contratación de mujeres. La Cámara hizo lugar a la acción y ordenó el cese de la discriminación; determinó que las empresas debían contratar mujeres hasta alcanzar un treinta por ciento (30 \%) de la planta de choferes. Agregó que la autoridad de aplicación de transporte local (la AMT), debía confeccionar una lista de todas las postulantes mujeres y ubicar a Mirtha Sisnero en primer lugar. Para el caso de que las empresas no cumplieran con lo ordenado, debían abonar a la primera en la lista un salario idéntico al del chofer de mejor remuneración. La Corte de Justicia de Salta revocó la sentencia. Sostuvo "síntomas discriminatorios en la sociedad" y observó que "basta detenerse en cualquier parada de colectivos para relevar la nula presencia de mujeres conduciendo estos móviles"; empero, revocó la sentencia por considerar que "no se configuró el presupuesto para que prospere el pedido de una orden de cese de discriminación". Por un lado, sostuvo que "la mera omisión de responder a las reiteradas solicitudes de trabajo de Mirtha Sisnero era insuficiente para tener por configurado un supuesto de discriminación porque las empresas no tenían ningún deber constitucional de responderle". Por el otro lado, intimó a las empresas demandadas a presentar ante la AMT los requisitos que exigen para la contratación de choferes. Por último, exhortó al Poder Legislativo y al Poder Ejecutivo provincial a emitir las normas necesarias para modificar los patrones socioculturales de discriminación. En su sentencia reconoció "la presencia de síntomas discriminatorios en la sociedad" porque en los hechos no hay mujeres choferes en Salta. Entonces, si bien no hizo lugar a la pretensión individual, hizo lugar parcialmente a la demanda "sólo a los fines preventivos, para que en futuras contrataciones se asegure que la postulación de mujeres será analizada por las empresas prestadoras sin tomar en cuenta su condición femenina sino en base a los mismos requisitos que los exigidos a los hombres". El caso llegó a la Corte por queja por recurso extraordinario federal denegado. La Corte Suprema dejó sin efecto la sentencia de la Corte Salteña, en tanto la Corte salteña no había valorado adecuadamente la prueba que constaba en el expediente. Recordó que la prueba es difícil de lograr en forma acabada para la parte que alega la discriminación. Por ello, "es suficiente con la acreditación de hechos que, prima facie evaluados, resulten idóneos para inducir su existencia, caso en el cual corresponderá al demandado, a quien se reprocha la comisión del trato impugnado, la prueba de que éste tuvo como causa un motivo objetivo y razonable ajeno a toda discriminación" (considerando 6). Si la actora lo logra la acreditación de "hechos de los que pueda presumirse su carácter discriminatorio", entonces es el demandado, en este caso las empresas, quienes deben probar que tuvieron "como causa un motivo objetivo y razonable ajeno a toda discriminación" (consid. 5). No basta con negar que no hubo intención de discriminar en la exclusión en la contratación, ni menos aún se puede basar esta prueba en imágenes estereotipadas acerca del papel de las mujeres en la sociedad, en este caso, salteña. La Corte reenvió la causa a la Corte provincial para que dictara nueva sentencia, CSJN, Sisnero, Mirtha Graciela y otros c. Tadelva SRL y otros s/amparo, 20/5/2014. V. análisis del fallo con referencia a la línea jurisprudencial de la Corte que fue haciendo camino al andar (Alvarez c. Cencosud (2010) Pellejero (2010) y Pellicori -2011), Zayat, Demián, "Hacia un definido Derecho Antidiscriminatorio", LA LEY 2014-D, 66. 
Sin embargo, lo hace implícitamente, cuando sostiene que esas explicaciones "resultan inadmisibles para destruir la presunción de que las demandadas han incurrido en conductas y prácticas discriminatorias contra las mujeres en general y contra Sisnero en particular." Insiste la Corte Suprema que se desprende de la propia sentencia de la Corte salteña que el reconocimiento de un contexto de discriminación contra las mujeres. Por eso parece cuestionarla cuando le reprocha implícitamente esa falta de observancia de la alerta interpretativa.

Lo traduzco en términos claros y sencillos a la manera de diálogo entre ambas Cortes: Si Ud. reconoce que los hechos se dan en un contexto de discriminación, por eso no se ven mujeres colectiveras, cómo no tener por probado que Sisnero es un caso de discriminación individual en el marco de la discriminación colectiva. Aún más, le advierte la Corte Suprema, en el expediente consta una entrevista a un empresario en un medio periodístico, que es un "claro ejemplo en esta dirección": "las manifestaciones de uno de los empresarios demandados ante un medio periodístico, quien, con relación a este juicio, señaló sin ambages y "entre risas" que "esto es Salta Turística, y las mujeres deberían demostrar sus artes culinarias [..]. Esas manos son para acariciar, no para estar llenas de callos [...] Se debe ordenar el tránsito de la ciudad, y [...] no es tiempo de que una mujer maneje colectivos [...]" ${ }^{43} \mathrm{Y}$, le agrega, no olvide Ud. que tengo jurisprudencia al respecto, no basta con que los empresarios afirmen que no tenían intención de discriminar. No veo los motivos "objetivos y razonables" que exige la jurisprudencia para "destruir la presunción" de discriminación.

Sin embargo, ni la Corte IDH ni la Corte Suprema explicita una metodología de análisis de estereotipos en los respectivos fallos. ${ }^{44}$ Este es el objetivo del artículo. Se trata de la reconstrucción de esos pasos.

\footnotetext{
43 CSJN, Sisnero, Mirtha Graciela y otros c/Tadelva SRL y otros s/amparo (2014), consid. 6.

44 Esto contrasta con otras herramientas utilizadas por la Corte IDH en otros contextos. Por ejemplo, cuando se trata de resolver la colisión entre la libertad de expresión y el derecho al honor, la Corte IDH expresamente establece que someterá la justificación a la solución
} 


\section{Caminos para detectar estereotipos}

Antes que nada conviene guiar el análisis a través de las siguientes preguntas generales formuladas por Rebecca Cook y Simone Cussak:

a) “¿Se está negando un beneficio a las mujeres en razón de la existencia de cierto estereotipo de género?"

b) “¿se le está imponiendo una carga a las mujeres en razón de la existencia de cierto estereotipo de género?"

c) “'se degrada a las mujeres, se les minimiza su dignidad o se las marginaliza de alguna manera en razón de la existencia de cierto estereotipo de género?"

Cuadro 1. Fuente: Elaboración del cuadro sobre la base de las preguntas en: Cook y Cussak (2010). ${ }^{45}$

Si volvemos la mirada sobre lo referido al caso Campo Algodonero o al caso Sisnero, sin lugar a dudas, las respuestas son afirmativas. Los estereotipos operan en contra de los derechos de las mujeres empeorando en Sisnero sus oportunidades para acceder a empleos mejor remunerados; ${ }^{46} \mathrm{y}$, en el caso, Campo Algodonero para ser buscadas en forma inmediata ante la denuncia de desaparición en un contexto de discriminación estructural contra las mujeres.

del conflicto a un examen de proporcionalidad. E incluso en la versión de examen de proporcionalidad estructurado ya que identifica con detalle los pasos a los cuales someterá la evaluación de la justificación estatal. V., por ejemplo, Corte IDH, Caso Kimel vs. Argentina.

45 Cook, Rebecca; Cusack, Simone, Estereotipos de género. Perspectivas legales transnacionales, Profamilia, Bogotá, 2010.

46 V. Coddou McManus, Alberto, (2017) “Addressing Poverty through a Transformative Approach to Anti-Discrimination Law in Latin America". en: Fortes P. , Boratti L., Palacios Lleras A., Gerald Daly T. (cords.) Law and Policy in Latin America. St Antony's Series. Palgrave Macmillan, London, quien sostiene que las normas antidiscriminatorios sirven para ver la pobreza como causal de discriminación y plantear el reclamo en clave de transformación de los procesos sociales, culturales, políticos y económicos que generan la dominación. En especial, estudia el caso de Argentina. Coddou McManus, Alberto, (2013). “Las interrogantes y posibilidades de un proyecto de derecho de la anti-discriminación en America Latina". En Estudios Constitucionales, Centro de Estudios Constitucionales de Chile, 2014, v.12, n. 2, pp. 315-322. 
Entonces, qué puede/debe hacer el o la jueza para desmantelar estereotipos. ${ }^{47}$ Las respuestas surgen de líneas de trabajos que presentan parecidos de familia, aunque no sean exactamente iguales. Nos referimos a los trabajos de Cook y Cussack, Timmer, Canosa Onofre, Undurraga, entre otras. ${ }^{48}$

Los operadores judiciales pueden hacer, por lo menos, dos cosas. La primera se refiere a que el propio tribunal no debe utilizar estereotipos en su argumentación. A su vez, debe formular las tres preguntas propuestas por Rebecca Cook y Simone Cussak para analizar la cuestión desde una perspectiva de género. Y, agregar, ¿consideran el contexto en la interpretación de los hechos y en la consideración de la prueba? ¿Están en una constante alerta interpretativa para no incurrir en forma expresa o implícita en el uso de estereotipos?

La segunda se refiere a su deber de revisión de los "argumentos" alegadas por el Estado en el caso de la Corte IDH o el razonamiento del tribunal inferior en el caso de la Corte Suprema. ${ }^{49}$ Alexandra Timmer identifica las siguientes etapas, que

\footnotetext{
47 Es una obligación estatal. La Convención sobre la eliminación de todas las formas de discriminación contra la mujer (CEDAW), establece en su artículo 5 que "Ios Estados Partes tomarán todas las medidas apropiadas para modificar los patrones socioculturales de conducta de hombres y mujeres, con miras a alcanzar la eliminación de los prejuicios y las prácticas consuetudinarias y de cualquier otra índole que estén basados en la idea de la inferioridad 0 superioridad de cualquiera de los sexos o en funciones estereotipadas de hombres y mujeres".

48 V. Cook, Rebecca; Cusack, Simone, Estereotipos de género. Perspectivas legales transnacionales, Profamilia, Bogotá, 2010; Cardoso Onofre de Alencar, Emanuela, Mujeres y estereotipos de género en la jurisprudencia de la Corte Interamericana de Derechos Humanos, en Eunomía. Revista en Cultura de la LegalidadNº 9 (Octubre 2015 - Marzo 2016), pp. 26-48. Sobre análisis de jurisprudencia desde perspectiva de género, v. Cecilia Ezpeleta, Carmen Colazo y Laura Cantore, "Igualdad, género y constitución: aportes feminista s para la reformulación del principio de igualdad. Análisis de fallos relevantes desde una perspectiva de género(s)", en Grosman, Legarre, Rivera, Elías (coord.), Tratado de Derechos Constitucionales, Abeledo Perrot/Thomson Reuters, Buenos Aires, 2014, pp. 958-1031; Clérico, Laura; Novelli, Celeste, "La inclusión de la cuestión social en la perspectiva de género: notas para re-escribir el caso "Campo Algodonero" sobre violencia de género", en: Revista de Ciencias Sociales, Valparaíso, Chile, 2016, pp. 453-487.
}

49 Esta identificación de estereotipos es lo que hace la Corte IDH en el mencionado caso Atala Riffo c. Chile. La Corte Suprema chilena y el Juzgado de Menores de Villarrica habían 
pueden ser consideradas parte de una metodología de trabajo: a) identificar estereotipos, b) enunciar, nombrar (naming) y desmantelar, ${ }^{50}$ los estereotipos que atraviesan el caso objeto de resolución y, además, c) evaluarlos como formas de discriminación (contesting) a través de un examen bien estricto de igualdad.

\begin{tabular}{|c|}
\hline Identificar \\
\hline Enunciar, nombrar y desenmascarar \\
\hline Evaluar intensamente \\
\hline
\end{tabular}

Cuadro 2. Fuente: Timmer (2013).

El objetivo de este apartado y los siguientes es poner a prueba la metodología reconstruida del texto de Timmer para aplicar en el contexto interamericano, toda vez que la autora la ensayó para el contexto europeo (TEDH). La Corte IDH es como el TEDH un tribunal regional de derechos humanos que aplica normas que contienen cláusulas de igualdad. La propia Corte IDH analiza casos en clave de "estereotipos", con lo que más allá de la propuesta concreta de Timmer, el abordaje no le es ajeno en tanto se basa en lo que surge de los informes del CEDAW y de otros organismos de protección de

establecido que la señora Atala había privilegiado sus intereses personales por sobre su papel de madre. La Corte IDH consideró, por el contrario, que exigirle a Karen Atala que condicionara sus opciones de vida implica utilizar una concepción "tradicional" sobre el rol social de las mujeres como madres, según la cual se espera socialmente que las mujeres lleven la responsabilidad principal en la crianza de sus hijos e hijas y que en pos de esto hubiera debido privilegiar la crianza de las y niñas renunciando a un aspecto esencial de su identidad. Por tanto, bajo esta motivación del supuesto privilegio de los intereses personales de la señora Atala tampoco se cumplía con el objetivo de proteger el interés superior de las tres niñas. Este mismo argumento sería trasladable a cualquier tipo de discriminación contra las mujeres cuando se las excluye sobre la base de estereotipos en relación con el "rol" de la "mujer" en la sociedad.

50 "Llamar a las cosas por su nombre y mostrar que ciertas formas de nombrar son violentas, es tarea pendiente para el poder judicial." Deza, Soledad,. "Brujas", estereotipos de género y violencia simbólica", LLN0A2013 (agosto), p. 719 (824). 
derechos humanos que están referidos en la sentencia de la Corte IDH en Campo Algodonero. A su vez, se trata de poner en diálogo la propuesta de Timmer y, en su caso, enriquecerla con preguntas que traccionan los casos que utilizamos como ejemplos o los textos sobre igualdad que permiten lecturas desde la multidimensionalidad ${ }^{51}$ de los procesos que producen y re-producen los estereotipos en perjuicio de mujeres, entre otras.

\section{a) Identificar, enunciar, nombrar}

A los efectos de identificar y enunciar ${ }^{52}$ estereotipos hay que realizar una serie de preguntas y reconstrucciones que tomo de Timmer pero que, a su vez, tienen reflejo en los documentos de la CEDAW. Están anunciadas en las tres preguntas de Cook y Cussack; y reformuladas en un lenguaje claro y sencillo en el ejercicio que plantea Undurraga (apartado I de este trabajo).

Así, para identificar, enunciar, nombrar y desenmascarar estereotipos se requiere tener en cuenta los siguientes puntos:

51 V. Laura Clérico; Celeste Novelli, "La inclusión de la cuestión social en la perspectiva de género: notas para re-escribir el caso "Campo Algodonero" sobre violencia de género", en: Revista de Ciencias Sociales, Valparaíso, Chile, 2016, pp. 453-487.

52 Entrevista a la Jueza Karen Atala, "Lesbofobia de Estado", en: Diario Página 12, 16/6/2017, accesible en: https://www.pagina12.com.ar/44360-lesbofobia-de-estado (última consulta 11/11/2017): "Me acuerdo de que el Ministro Visitador de mi tribunal (en Argentina sería el equivale a camarista) me llama a su oficina. $Y$ me dice: la cité porque tengo entendido que su ex marido la acaba de demandar de tuición porque usted sería lesbiana. Le dijo: Sí, su Señoría, pero es un tema privado. Me contesta: le quiero pedir que evite hacer todo tipo de escándalo por el prestigio del poder judicial y que en lo posible entregue sus hijas a su marido para evitar mayores escándalos. Le dije: "me parece preocupante lo que me dice puesto que usted ministro, esta casa está recién empezando en el tribunal de primera instancia. Eventualmente, sea una sentencia favorable o no, va a llegar a la corte. Y usted va a tener que conocerla, intervenir en algún momento y voy a tener que pedir que se lo inhabilite". Ahí el ministro tomó el peso de lo que estaba diciendo. Era, claro, una intromisión arbitraria en mi vida privada. Eso demuestra el profundo machismo. En 2003 no se hablaba ni se conocía de lesbianas allí en la zona. Mi caso sirvió para darles cara y visibilidad a las lesbianas en Chile. Lo que no se enuncia, no existe." 
una "reconstrucción comprensiva del contexto histórico, económico, político, cultural, social;" y trabajar las siguientes preguntas:

"¿los hechos y el contexto se enmarca en una historia de discriminación de género o por orientación sexual o identidad o expresión de género?",

“¿cuáles son los efectos actuales para las personas concretas, grupos, situaciones, estados de cosas, relaciones? ¿Cuáles son los procesos, prácticas, instituciones, estructuras, que generan y alimentan esos estereotipos?"

Cuadro 3. Fuente: Timmer (2013).

En el caso Campo Algodonero, las mujeres desaparecidas fueron tomadas en forma estereotipada como jóvenes en situación de coqueteo con sus novios y que llegarían de regreso a sus casas después de haberla pasado bien. A su vez, se presume que las mujeres desaparecidas se habrían, en todo caso, buscado ese destino porque no respondían a la imagen petrificada de lo que se espera de una "mujer de bien", estar en su casa.

Estos estereotipos son/deben ser leídos en el contexto de una cultura de discriminación contra las mujeres en México. ${ }^{53}$ La Corte IDH toma nota que el Estado, alega que: "uno de los factores estructurales que ha motivado situaciones de violencia contra las mujeres en Ciudad Juárez es la modificación de los roles familiares que generó la vida laboral de las mujeres. (...) los roles tradicionales empezaron a modificarse, al ser ahora la mujer la proveedora del hogar (...) Esto, según el Estado, llevó a conflictos al interior de las familias porque la mujer empezó a tener la imagen de ser más competitiva e independiente económicamente". ${ }^{54}$ Continúa que es el propio Estado quien reconoce que estos mecanismos responden a una "cultura fuertemente arraigada en estereotipos, cuya piedra angular es el supuesto de la inferioridad de las mujeres" y que "no se cambia de la noche a la mañana. El cambio de patrones culturales es

53 Corte IDH, Caso Campo Algodonero, párrafos 128-136.

${ }^{54}$ Corte IDH, Caso Campo Algodonero, párr. 129. 
una tarea difícil para cualquier gobierno." ${ }^{55}$ Así todo se explicaría por el patrón cultural ${ }^{56}$ dominante del patriarcado. ${ }^{57}$ Se basa sobre un informe de la Relatoría de la CIDH que señala que la violencia contra las mujeres en Ciudad Juárez "tiene sus raíces en conceptos referentes a la inferioridad y subordinación de las mujeres" 58 . Un informe del CEDAW le sirve para comprender que "no se trata de casos aislados, esporádicos o episódicos de violencia, sino de una situación estructural y de un fenómeno social y cultural enraizado en las costumbres y mentalidades" y nuevamente que estas situaciones están fundadas "en una cultura de violencia y discriminación basada en el género". ${ }^{59}$ La Corte realiza una reconstrucción del contexto, enmarca los hechos del caso y el contexto en una historia de discriminación de género. Le permite ver que los efectos actuales para las personas que son víctimas de violaciones a derechos humanos. En suma, las preguntas del cuadro 3 permiten identificar estereotipos.

De regreso al caso Sisnero ${ }^{60}$ sobre discriminación contra las mujeres en la selección de personal para ocupar puestos

55 Corte IDH, Caso Campo Algodonero, párr. 132 con referencia al Informe de México producido por el CEDAW bajo el Artículo 8 del Protocolo Facultativo de la Convención y respuesta del Gobierno de México, CEDAW/C/2005/OP. 8/MEXICO, 27 de enero de 2005.

56 V. Laura Clérico; Celeste Novelli, "La inclusión de la cuestión social en la perspectiva de género: notas para re-escribir el caso "Campo Algodonero" sobre violencia de género", en: Revista de Ciencias Sociales, Valparaíso, Chile, 2016, pp. 453-487; asimismo, Bórquez, Natalia, "Hacia Una Igualdad Transformadora En Las Producciones De La Corte Y De La Comisión Interamericana De Derechos Humanos. Derechos Sociales, Mujeres Y Maquilas", en: Revista Electrónica Instituto de Investigaciones Jurídicas y Sociales Gioja, 2017, Nro. 19 (aceptado, en trámite de publicación).

57 Corte IDH, Caso Campo Algodonero, v. nota al pie de página Nro. 3 en este trabajo.

58 Corte IDH, Caso Campo Algodonero, párr. 133. En este párrafo la Corte cita el Informe de la CIDH sobre la situación de los derechos de la mujer en Ciudad Juárez, México: el derecho a no ser objeto de violencia y discriminación, OEA/Ser.L/V/II.117 Doc. 1 rev. 1, 7 de marzo de 2003, párr. 128.

59 Ídem. En este párrafo la Corte cita el Informe de México producido por el CEDAW bajo el Artículo 8 del Protocolo Facultativo de la Convención y respuesta del Gobierno de México, CEDAW/C/2005/OP. 8/MEXICO, 27 de enero de 2005, párrs. 159 y 261.

60 CSJN, Sisnero, Mirtha Graciela y otros c. Tadelva SRL y otros s/amparo, 20/5/2014. 
de trabajo de colectivera. La Corte Suprema no habla expresamente de estereotipo, es claro que en la trastienda subyace ese concepto. La Corte salteña reconoce un contexto discriminatorio ${ }^{61}$ cuando advierte sobre "síntomas discriminatorios en la sociedad". Estos explicarían "la ausencia de mujeres en un empleo como el de chofer de colectivos". Sin embargo la Corte salteña, no tiene por acreditada la discriminación en el caso individual de Sisnero. Como reconstruimos arriba, la Corte nacional le reprocharía a la Corte salteña, que no logra vislumbrar que las sinrazones alegadas por los empresarios para derribar la presunción discriminatoria, que pesa sobre la práctica de contratación, ${ }^{62}$ implican estereotipos de género. Estos estereotipos son causa y consecuencia de "un mercado laboral segregado en perjuicio de las mujeres", como señala la Procuración. ${ }^{63}$

Esos estereotipos quedan patentes en los dichos del empresario de transporte vertidos en una entrevista periodística y agregada al expediente. La entrevista puede reformularse como una alegación de que las mujeres deben corresponderse con lo que se espera de ellas, deben asimilarse al patrón social esperado. Las mujeres aparecerían como parte del paisaje salteño. A su vez, debe servir los deseos de los otros, para ello su piel debe permanecer tersa para acariciar. A lo sumo, debe

\footnotetext{
61 "La situación de la mujer no mejorará mientras las causas subyacentes de la discriminación contra ella y de su desigualdad no se aborden de manera efectiva. La vida de la mujer y la vida del hombre deben enfocarse teniendo en cuenta su contexto y deben adoptarse medidas para transformar realmente las oportunidades, las instituciones y los sistemas de modo que dejen de basarse en pautas de vida y paradigmas de poder masculinos determinados históricamente." Comité CEDAW, Recomendación general No. 25, sobre el párrafo 1 del artículo 4 de la Convención sobre la eliminación de todas las formas de discriminación contra la mujer, referente a medidas especiales de carácter temporal, $30^{\circ}$ período de sesiones, 2004, párr. 10. Énfasis y cursiva agregadas.

62 CSJN, Sisnero, Mirtha Graciela y otros c. Tadelva SRL y otros s/amparo, 20/5/2014, considerandos 5 y 6 .

63 Dictamen de la Procuración, punto IV. V. Pou, Francisca, "Estereotipos, daño dignitario y patrones sistémicos: la discriminación por edad y género en el mercado laboral", en Revista Discusiones (portal DOXA), 2015, pp. 147-188, quien advierte sobre el carácter más completo de la argumentación del dictamen en comparación con el fallo de la Corte.
} 
aspirar a ser cocinera, dedicarse a las tareas culinarias (adviértase, trabajo mal remunerado adjudicado por mandato social a las mujeres), y de ningún modo a ser colectiveras porque desarrollarían callos en sus manos. ${ }^{64}$ Las segrega así de puestos de trabajo mejor remunerados.

Tanto el caso Campo Algodonero como Sisnero permiten ejemplificar la identificación del estereotipo, la referencia al contexto ampliado y el efecto perjudicial para las mujeres de Ciudad de Juárez, por un lado, y Sisnero y las mujeres de Salta por el otro lado. La identificación de estereotipos aparece como instantáneas recortadas de los procesos sociales, económicos y culturales que ponen al colectivo mujeres en situación de subordinación y desigualdad para el acceso al ejercicio de los derechos (art. 75 inc. $23 \mathrm{CN}$ ).

\section{b) Des-enmascarar los estereotipos}

Una vez identificado, enunciado y nombrado el estereotipo que perjudica a la persona o colectivo afectado, este queda inhibido de ser utilizado como razón para justificar el incumplimiento de una obligación estatal como en los casos de violencia de género en Ciudad de Juárez o, en el orden interno, de obligaciones de empresas privadas prestatarias del servicio público de transporte de personas como en el caso Sisnero (que no olvidemos deben estar bajo el contralor del Estado). Además, el artículo 5(a) de la CEDAW y en los artículos 6(b) y 8(b) de la Convención Belem do Para, establece la obligación estatal de erradicar los estereotipos de género, mal puede entonces ser usado como "razón" para justificar un trato en desmedro de la persona afectada.

En Campo Algodonero los estereotipos sobre las mujeres desaparecidas se refirieron a "mujer volada", "mujer deshonesta", "mujer no casta". Estos inhibieron injustificadamente a los agentes policiales de actuar en forma inmediata para la

64 CSJN, Sisnero, Mirtha Graciela y otros c. Tadelva SRL y otros s/amparo, 20/5/2014, consid. 6 . 
búsqueda de las víctimas. Implican violaciones claras a los derechos de las mujeres. Estas imágenes estereotipadas no pueden ser utilizadas por el Estado para justificar el incumplimiento de su obligación de prevención, protección e investigación eficaz en el caso. En forma más reciente la Corte IDH señaló en otro caso sobre violencia de género que:

la influencia de patrones socioculturales discriminatorios puede dar como resultado una descalificación de la credibilidad de la víctima durante el proceso penal en casos de violencia y una asunción tácita de responsabilidad de ella por los hechos, ya sea por su forma de vestir, por su ocupación laboral, conducta sexual, relación o parentesco con el agresor, lo cual se traduce en inacción por parte de los fiscales, policías y jueces ante denuncias de hechos violentos. Esta influencia también puede afectar en forma negativa la investigación de los casos y la valoración de la prueba subsiguiente, que puede verse marcada por nociones estereotipadas sobre cuál debe ser el comportamiento de las mujeres en sus relaciones interpersonales. Es así que según determinadas pautas internacionales en materia de violencia contra la mujer y violencia sexual, las pruebas relativas a los antecedentes sexuales de la víctima son en principio inadmisibles, por lo que la apertura de líneas de investigación sobre el comportamiento social o sexual previo de las víctimas en casos de violencia de género no es más que la manifestación de políticas o actitudes basadas en estereotipos de género ${ }^{65}$.

Identificar el estereotipo le permitió desenmascarar las referencias a crímenes "pasionales" como suelen ser caracterizados la violencia de género: "el concepto de crimen pasional es parte de un estereotipo que justifica la violencia contra la mujer. El calificativo 'pasional' pone el acento en justificar la conducta del agresor". Por ejemplo, "'la mató por celos', 'en un ataque de furia', son expresiones que promueven la condena a la mujer

65 Corte IDH, caso Gutierrez Hernández vs. Guatemala, párr. 170; cfr. Caso Véliz Franco y otros vs. Guatemala, párr. 209. 
que sufrió violencia. Se culpabiliza a la víctima y se respalda la acción violenta del agresor" ${ }^{\prime 6}$. En este sentido, el Tribunal "rechaza toda práctica estatal mediante la cual se justifica la violencia contra la mujer y se le culpabiliza de ésta, toda vez que valoraciones de esta naturaleza muestran un criterio discrecional y discriminatorio con base en el comportamiento de la víctima por el solo hecho de ser mujer. Consecuentemente, considera que estos estereotipos de género son incompatibles con el derecho internacional de los derechos humanos y se deben tomar medidas para erradicarlos donde se presenten." ${ }^{67}$ Así, concluye que a "este respecto cabe insistir en general en la necesidad de descalificar la práctica de devaluación de la víctima en función de cualquier estereotipo negativo, idónea para culpabilizar a una víctima, y neutralizar la desvaloración de eventuales responsables." En suma, los estereotipos no pueden ser utilizados como exculpatorios de la responsabilidad de los perpetradores y a la postre para alivianar el deber de investigación $^{68}$ estatal adecuada y eficaz. $^{69}$

En especial, resulta importante para poner la práctica en contexto, que el propio tribunal tenga en cuenta casos similares resueltos que reconocen un mismo patrón de estereotipos: "Por otra parte, la Corte advierte que las prácticas seguidas por los funcionarios a cargo de la investigación de la desaparición de Mayra Gutiérrez no son un hecho aislado, pues ha sido detectada

66 Corte IDH, caso Gutiérrez Hernández vs. Guatemala, cursiva agregada; v. Caso Velásquez Paiz y otros vs. Guatemala, párr. 187.

67 Corte IDH, caso Gutiérrez Hernández vs. Guatemala, párr. 171.

68 Corte IDH, caso Gutiérrez Hernández vs. Guatemala: “En consecuencia, tal y como lo ha hecho anteriormente, este Tribunal considera que las referidas omisiones investigativas relacionadas con la falta de seguimiento de líneas lógicas de investigación, fueron una consecuencia directa de una práctica común de las autoridades encargadas de la investigación, orientadas hacia una valoración estereotipada de la víctima, lo que aunado a la ausencia de controles administrativos y/o jurisdiccionales que posibilitaran la verificación de las investigaciones en este tipo de casos, así como la rectificación de las irregularidades presentadas, afectó la objetividad de dichas autoridades, denegándose, además, el derecho al acceso a la justicia de la señora Mayra Gutiérrez y sus familiares." Cursiva agregada.

${ }^{69}$ Corte IDH, caso Gutiérrez Hernández vs. Guatemala, párrs. 174-176. 
reiteradamente por este Tribunal en los casos Veliz Franco $y$ otros, y Velásquez Paiz y otros, contra Guatemala, la tendencia de los investigadores a desacreditar a las víctimas y culpabilizarlas por su estilo de vida, o ropa, así como a indagar aspectos relativos a las relaciones personales y sexualidad de las víctimas para concluir que esas personas fueron responsables de lo que les pasó, y la existencia de estereotipos y prejuicios de género con influencia negativa en la investigación, en la medida en que trasladaron la culpa de lo acontecido a la víctima y a sus familiares, cerrando otras líneas posibles de investigación sobre las circunstancias del caso e identificación de los autores ${ }^{70}$." Esto ayuda al tribunal para develar que en el caso particular bajo estudio, el de Mayra Gutiérrez, "se observa la utilización de un estereotipo para culpabilizar a la víctima de lo sucedido, excluyendo las demás hipótesis y desechando cualquier otra línea de investigación, como aquella relacionada con los trabajos realizados por la presunta víctima sobre la adopción y tráfico de niñas y niños en Guatemala y la denuncia sobre su presunta desaparición forzada." 71

Por su parte, la Corte Suprema en Sisnero concluye, reiteramos, que las "dogmáticas explicaciones esbozadas por las empresas resultan inadmisibles para destruir la presunción de que las demandadas han incurrido en conductas y prácticas discriminatorias contra las mujeres en general y contra Sisnero, en particular". Es que este tipo de defensas -que, en definitiva, se limitan a negar la intención discriminatoria- no pueden ser calificados como un motivo objetivo y razonable". ${ }^{72}$ En este sentido, tampoco es atendible el uso del estereotipo de las mujeres como acariciadoras natas o cocineras para excusarse de contratar a mujeres para desempeñarse como colectiveras.

70 Corte IDH, caso Gutierrez Hernández vs. Guatemala; asimismo,. Caso Veliz Franco y otros vs. Guatemala, párrs. 90, 210 a 212, y Caso Velásquez Paiz y otros vs. Guatemala, párrs. 49, 210-212.

71 Corte IDH, caso Gutierrez Hernández vs. Guatemala.

72 CSJN, Sisnero, consid. 6. 


\section{c) Evaluarlos como forma de discriminación y excluirlos}

\section{como argumentos}

Si en el primer paso se identificaron, nombraron, enunciaron y des-enmascararon estereotipos de género que generan perjuicio, entonces se aplica una presunción en contra de la justificación de la acción u omisión estatal, esto es:

la carga de la argumentación recae en cabeza del Estado,

la carga de la justificación agravada (razones de mucho peso), consideraciones excluidas, no se pueden basar en el uso de estereotipos,

ningún margen de apreciación para el Estado,

si al final de la argumentación persisten dudas, la medida estatal queda como injustificada.

Cuadro 4. Fuente: reconstrucción jurisprudencial sobre casos de igualdad.

Al respecto, resulta ilustrativo el caso de la Corte IDH Atala Riffo c. Chile sobre discriminación por orientación sexual y género en el caso de una mujer divorciada que le revocan la tuición de sus tres niñas por haber iniciado la mujer una relación con otra mujer. La Corte IDH resalta que algunos actos discriminatorios analizados "se relacionaron con la reproducción de estereotipos que están asociados a la discriminación estructural e histórica que han sufrido las minorías sexuales, particularmente en cuestiones relacionadas con el acceso a la justicia y la aplicación del derecho interno." ${ }^{73}$ Lo primero que hace la sentencia es desarticular esos estereotipos en la argumentación de las decisiones que se tomaron en el orden interno. Al respecto, surge, de la reconstrucción del fallo de la Corte IDH, la siguiente regla: cuando una clasificación está prohibida, significa que el Estado que quiera excluir a alguna persona de lo que le otorga a otra debe basar ese trato diferenciado en razones de peso que nada tengan que ver con la orientación sexual de las personas. Dos fueron los actos estatales que fueron analizados

\footnotetext{
73 Corte IDH, caso Atala, párr. 267 y 92.
} 
para evaluar si estos resultaron discriminatorios: i) la sentencia que resolvió el recurso de queja, y ii) la decisión de tuición provisional. Para analizar si existió un "vínculo o nexo causal o decisivo entre la orientación sexual de la señora Atala y las decisiones de la Corte Suprema de Justicia de Chile y del Juzgado de Menores de Villarrica".

Entonces, un trato diferenciado en desmedro de los derechos de una persona LGBTI nunca podría ser justificado por la orientación sexual, sería una suerte de razón excluida de la argumentación. Esta condición social no puede ser tenida en cuenta como elemento para decidir sobre una tuición o custodia en aras del interés superior de las niñas. Por ello, el trato diferenciado debería basarse en razones independientes de la orientación sexual de las personas, de lo contrario se incurre en discriminación. Y, "es el Estado el que tiene la carga de la prueba para mostrar que la decisión judicial objeto del debate se ha basado en la existencia de un daño concreto, específico y real en el desarrollo de las niñas." " Este estándar es mucho más exigente que el del mero daño especulativo esgrimido por las sentencias en los procesos de tuición. En el caso, el tribunal interno se limitó a hacer referencia, respecto al supuesto daño, a la "eventual confusión de roles sexuales" y la "situación de riesgo para el desarrollo" de las niñas ${ }^{75}$. Para aprobar con éxito el estándar del daño concreto, específico y real, es necesario que en las decisiones judiciales sobre temas de tuición se definan de manera específica y concreta los elementos de conexidad y causalidad entre la conducta de la madre o el padre y el supuesto impacto en el desarrollo del niño o la niña.

Esta relación de conexidad no queda demostrada si, el Estado alega: a) la pre-concepción, no sustentada, de que los niños criados por parejas homosexuales necesariamente

\footnotetext{
74 Párr. 124, cfr. 131.

75 Párr. 129, con cita de la sentencia de la Corte Suprema de Justicia de Chile de 31 de mayo de 2004.
} 
tendrían dificultades para definir roles de género o sexuales, ${ }^{76}$ b) la presunta discriminación social que habrían sufrido las tres niñas por la orientación sexual de la señora Atala, ${ }^{77}$ (antes bien, es el Estado el obligado a que los niños y niñas no sean discriminados en las escuelas), c) la supuesta prevalencia que la señora Atala le habría dado a su vida personal sobre los intereses de sus tres hijas toda vez que esto está basado en un estereotipo de género que supone que una "buena mujer" pospone cualquier cosa por la crianza de sus niñas suponiendo a su vez que una madre lesbiana es una mala madre, ${ }^{78} \mathrm{y} \mathrm{d}$ ) el derecho de las niñas a vivir en el seno de una familia con un padre y una madre ${ }^{79}$ ("modelo tradicional"), cuando la Corte IDH tiene jurisprudencia que reitera que la Convención protege una pluralidad de familias y no solo la que responde a la tradicional. En suma, detrás de todas las razones alegadas por el Estado, subyace algún estereotipo que se refieren a la orientación sexual de las personas, al género o a la concepción tradicional de la familia.

En general la Corte IDH en el caso Atala realiza un examen de igualdad en una versión de escrutinio bien estricto. Por lo demás, sobre el final de la sentencia la Corte IDH amplia la mirada incluyendo el contexto en el que se produce la (des)igualdad. Así relaciona la reproducción de estereotipos con:

"la discriminación estructural e bistórica que ban sufrido las minorías sexuales". Por ello, concluye que "algunas de las reparaciones deben tener una vocación transformadora de dicha situación, de tal forma que las mismas tengan un efecto no solo restitutivo sino también correctivo ${ }^{80}$ hacia cambios estructurales que desarticulen

\footnotetext{
76 Sentencia de la Corte Suprema de Justicia de Chile de 31 de mayo de 2004 (expediente de anexos a la demanda, tomo V, folio 2672). Corte IDH, párrafos 123; 131; 127; 130.

77 Sentencia de la Corte Suprema de Justicia de Chile de 31 de mayo de 2004.

78 Sentencia de la Corte Suprema de Justicia de Chile de 31 de mayo de 2004.

79 Sentencia de la Corte Suprema de Justicia de Chile de 31 de mayo de 2004.

80 En similar sentido, cfr. Caso González y otras (“Campo Algodonero”), párr. 450.
} 
aquellos estereotipos y prácticas que perpetúan la discriminación contra la población LGTBI." ${ }^{\prime 1}$

Esta argumentación se puede reconstruir en clave de identificación de estereotipos, consideración del contexto para ubicar el carácter estructural del perjuicio contra el colectivo LGBTTI, descalificación de los argumentos que se basan en estereotipos, aplicación de un examen intensivo de igualdad. Menos explorada está en la sentencia la multidimensionalidad de la desigualdad. La sentencia ve correctamente que el modelo dominante desde el que se concibe la orientación sexual, genera identidades menospreciadas. ${ }^{82}$ Este fue el motor para quitarle la tuición a Atala. Sin embargo, esta es solo una cara de la moneda. Las subjetividades no respetadas tienen mayores obstáculos para acceder al mundo del trabajo formal y remunerado. El caso claro es el de las personas trans. ${ }^{83}$ Es también el

81 Caso Atala, párr. 267.

82 Se trata de una concepción de igualdad como reconocimiento. En otro lugar explicamos que la idea de igualdad como reconocimiento busca resolver el problema de la formación de la subjetividad apuntando a los déficits que, en términos de acceso a los recursos simbólicos, fracturan a la sociedad en subjetividades dominantes y dominadas. Desde esta perspectiva, la naturalización del estado de cosas vigentes y la obturación de los intereses de aquellos que no pertenecen a los grupos dominantes se traduce en la legitimación de las desigualdades de status dentro de la sociedad y el aumento de la brecha entre unos y otros. Lo que define a esta perspectiva es su creencia en que es la transformación de los patrones de representación cultural lo que permitiría resolver las injusticias sociales. En este sentido proponen la revaluación de subjetividades no respetadas, en nuestro caso, la de los colectivos LGBTTI; .Clérico, Laura; Aldao Martín, “Nuevas miradas de la igualdad en la jurisprudencia de la Corte Interamericana de Derechos Humanos: la igualdad como redistribución y como reconocimiento", Revista Estudios Constitucionales, Facultad de Derecho/Universidad de Talca, Santiago/Chile, julio 2011 (disponible también en: http://www.scielo.cl/pdf/estconst/ v9n1/art06.pdf). FRASER, Nancy: Iustitia Interrupta. Siglo de Hombres Editores/Universidad de los Andes, Bogotá, 1997. FRASER, Nancy: Escalas de Justicia. Herder, Barcelona, 2008.

$83 \mathrm{CIDH}$, Informe sobre la "Violencia contra personas LGBTI", 2015, "la violencia generalizada, los prejuicios y la discriminación en la sociedad en general y dentro de la familia, obstaculizan las posibilidades de que personas trans tengan acceso a educación, servicios de salud, vivienda y al mercado laboral formal". La violencia, discriminación y estigmatización que las personas trans sufren las inserta en un ciclo de exclusión que tiende a culminar en la pobreza, en función de la falta de acceso a servicios básicos, oportunidades educativas y laborales y prestaciones sociales. Este ciclo de exclusión comienza generalmente desde 
caso de muchas mujeres. Incluso, aquellas que tienen acceso a cargos de jueza, como la jueza Atala, pueden sufrir la iniciación de procesos disciplinarios o similares. ${ }^{84}$ La Corte IDH considera que el procedimiento administrativo se inició por la orientación sexual de Atala y es tachado por parcial. Esta faz de la sentencia habla de que las identidades desaventajadas sufren perjuicios en el acceso, permanencia y promoción en sus profesiones, acceso al mundo del trabajo, entre otras. Habilitaría entonces poner de relieve que el problema está también en la estructura institucional y socio-económica que genera desigualdad ${ }^{85}$ y que

muy temprana edad, debido al rechazo y violencia sufrida por niñas/os y adolescentes trans y de género diverso en sus hogares, comunidades y centros educativos. Esta situación tiende a impedir que este grupo acceda y complete los diferentes niveles educativos, lo cual impacta negativamente sobre su calidad de vida." A su vez, en forma más específica la Relatora Especial de Derechos Económicos, Sociales, Culturales y Ambientales (REDESCA) de la CIDH, Soledad García Muñoz, instó a que: "Las políticas de reconocimiento que avanzan en la región, referidas por ejemplo a leyes de no discriminación, identidad de género, unión civil o matrimonio igualitario, deben suponer también avances en el acceso a los derechos a la educación, la salud, el trabajo, entre otras, tanto de las personas LGBTI como de sus familiares, sin discriminación. Desde la perspectiva de indivisibilidad de derechos, el progreso en derechos civiles debe expresarse en avances en el acceso a los DESCA". V. CIDH, Comunicado de Prensa, “En el Día Internacional de la Memoria Trans, la CIDH urge a los Estados a garantizar el pleno acceso de las personas trans a sus derechos económicos, sociales, y culturales", 20.11.2017, en: http://www.oas.org/es/cidh/prensa/comunicados/2017/185. asp (última consulta 21/11/2017).

84 Entrevista a la Jueza Karen Atala, "Lesbofobia de Estado", en: Diario Página 12, 16/6/2017, accesible en: https://www.pagina12.com.ar/44360-lesbofobia-de-estado (última consulta 11/11/2017): "Las mujeres lesbianas cargamos con los prejuicios machistas. Ya de partida nos cuesta posicionarnos en nuestros espacios de trabajo, nos cuesta la equidad de sueldos para las mismas tareas. Súmale además a esa mochila el hecho de que eres lesbiana. Es muy poco visible el lesbianismo en los espacios públicos." Cursiva agregada.

85 Clérico, Laura y Aldao, Martín: "La Igualdad como Redistribución y como Reconocimiento: Derechos de los Pueblos Indígenas y Corte Interamericana de Derechos Humanos". En: Revista Estudios Constitucionales, Universidad de Talca, Año 9, Núm. 1, 2011, p. 167: “La idea de igualdad como redistribución (...) apunta a los déficits que en, términos de acceso a recursos materiales, fracturan a la sociedad en propietarios, asalariados y desposeídos. Desde esta perspectiva, la naturalización del estado de cosas vigentes y la obturación de los intereses de aquellos que no pertenecen a los grupos dominantes se traduce en legitimación de las desigualdades en términos de acceso a recursos materiales y aumento de la brecha entre ricos y pobres. De este modo se produce un círculo vicioso en el cual las desigualdades de propiedad no pueden ser alteradas por el principio de igualdad formal, reforzando 
pone a las mujeres de ser pasibles de ser sancionadas en su trabajo por su género y orientación sexual. ${ }^{86}$

Por su parte, la Corte Suprema argentina en el caso Sisnero, no llega a implementar un examen de igualdad. Faltaban elementos porque a primera vista surgía que el empresariado

las dificultades de acceso de trabajadores y desposeídos a las instancias de participación política, que son a su vez las únicas que podrían modificar esta estrecha comprensión de la igualdad. Lo que define a esta particular perspectiva de la justicia social es su creencia en que la transformación de las relaciones de producción constituye el remedio fundamental para la solución de las desigualdades. En este sentido proponen la redistribución del ingreso o la riqueza, la redistribución de la división del trabajo y la reestructuración de la propiedad privada y de la empresa entre otros. A su vez, identifican en la clase desposeída de recursos al principal grupo afectado; y a la eliminación de las diferencias materiales como la solución a la desigualdad, a lo que se suma el cuestionamiento, en sus versiones más radicales, de los criterios que se utilizan para definir el acceso a la producción." Disponible en: http://www. cecoch.cl/docs/pdf/revista_9_1_2011/08.\%20LA\%20IGUALDAD_CLERICO_ALDA0.pdf.

86 La Com. IDH advierte la estrecha relación entre la violencia de género y la falta de acceso a los derechos sociales, económicos y culturales. Sostiene que "Aunque la pobreza afecta a todas las personas, su impacto es diferente para las mujeres, dada su situación de discriminación social y la existencia de cargas adicionales, tales como las funciones familiares, lo cual limita sus posibilidades de acceder a los recursos económicos necesarios para su subsistencia, y la de sus familias. Asimismo, las desigualdades y limitaciones en el acceso y control de recursos económicos por parte de las mujeres contribuye a su baja participación en esferas vitales para sus derechos humanos." CIDH, El trabajo, la educación y los recursos de las mujeres: la ruta hacia la igualdad en la garantía de los derechos económicos, sociales y culturales, OEA/Ser.L/V/II.143 Doc. 59, 3 de noviembre de 2011, párr. 25. Por el otro lado, en forma más reciente en el Informe de la Comisión sobre "Mujeres Indígenas Desaparecidas y Asesinadas en Columbia Británica, Canadá" (2014), sostiene: "Las autoridades canadienses y las organizaciones de la sociedad civil coinciden en gran medida sobre las causas de esta situación, que se relacionan con una historia de discriminación que se inicia con la colonización. Como consecuencia de esta discriminación histórica, la CIDH observa que las niñas y mujeres indígenas constituyen uno de los grupos más desventajados en Canadá. La pobreza, la vivienda inadecuada, y la relegación económica y social, entre otros factores, contribuyen a su mayor vulnerabilidad a la violencia. Adicionalmente, las actitudes prevalentes de discriminación -principalmente relacionadas con el género y la raza- y los estereotipos arraigados a los que se han visto sujetas, exacerban su vulnerabilidad. La ausencia de debida diligencia en casos de violencia contra las mujeres indígenas es especialmente grave, pues afecta no solamente a las víctimas, sino también a sus familias y a las comunidades a las que pertenecen. La CIDH subraya que abordar la violencia contra las mujeres indígenas no es suficiente a menos que los factores subyacentes de la discriminación racial y de género que originan y exacerban la violencia sean abordados de forma abarcativa." $\mathrm{CIDH}$, Mujeres Indígenas Desaparecidas y Asesinadas en Columbia Británica, Canadá, OEA/Ser.L/V/II. Doc. 30/14, 21/12/2014. Cursiva agregada. 
sustentaba la exclusión de mujeres para la selección de choferes de colectivos, en meras afirmaciones dogmáticas. Recordemos que incluso utilizó estereotipos de género en aras de explicar su práctica segregativa de contratación. Estos estereotipos fueron descalificados desde el principio como posible argumentos para justificar los motivos objetivos $\mathrm{y}$ razonables que la Corte exigía para dar la práctica de contratación como no-discriminatoria. Sisnero abona una línea jurisprudencial de la Corte sobre discriminación por género en el mundo del trabajo formal y remunerado. La Corte aplica el estándar de la carga de la prueba dinámica. En estos casos es difícil demostrar en forma acabada la discriminación para el colectivo afectado, por ello sostiene: "Para la parte que invoca un acto discriminatorio, es suficiente con la acreditación de los hechos que, prima facie evaluados, resulten idóneos para inducir su existencia”. En el caso estaba acreditada prima facie a través de las listas de contratación que arrojaban como resultado choferes solo varones, incluso luego de que Sisnero hubiese aspirado al puesto, por entrevistas agregadas al expediente basadas en estereotipos de género y por un clima concordante de discriminación social como parte del contexto. Entonces, el estándar establece, que acreditada prima facie la discriminación, "corresponderá al demandado, a quien se reprocha la comisión del trato impugnado, la prueba de que éste tuvo como causa un motivo objetivo y razonable ajeno a toda discriminación, y si el reclamante puede acreditar la existencia de hechos de los que pueda presumirse su carácter discriminatorio, corresponderá al demandado la prueba de su inexistencia." Por ello, revocó la decisión de la Corte de Salta que había revocado, a su vez, la sentencia que había admitido el amparo individual y ordenado el cese de la discriminación por razones de género. La Corte Suprema sostuvo que la Corte de Salta no había valorado adecuadamente la prueba obrante en el expediente que acreditaba la discriminación. Asimismo, le recriminó no haber aplicado los criterios de la Corte Suprema en materia de cargas probatorias. Por ello concluyó, insistimos, 
que "las dogmáticas explicaciones esbozadas por las empresas resultan inadmisibles para destruir la presunción de que las demandadas han incurrido en conductas y prácticas discriminatorias contra las mujeres en general y contra la actora en particular." Esta línea jurisprudencia tiene proyecciones que exceden el caso concreto. La carga dinámica de la prueba está también pensada para evitar el efecto disuasivo frente a otros posibles casos de discriminación por género. Si la carga es muy dificultosa para el colectivo discriminado afectado, ${ }^{87}$ esto disuadirá a otras de atacar prácticas sistemáticas de discriminación.

Por último, respecto de las razones que debe alegar el demandado, se identifica aquí un punto divergente entre el dictamen de la Procuración y la sentencia de la Corte Suprema. A esta última le alcanza con que el demandado demuestre un motivo objetivo y razonable. En cambio, en el dictamen de la Procuración se exige un mayor peso de las razones. Considera que la discriminación contra las mujeres en el caso del acceso a la profesión de colectiveras es sospechosa, ${ }^{88}$ que exige un escrutinio más intensivo. A su vez, el uso de estereotipos de género perjudiciales para el colectivo afectado justifica ese tipo de análisis. En cambio, la Corte Suprema parece pronunciarse por un examen intermedio en Sisnero.

87 CSJN, Sisnero, Mirtha Graciela y otros c. Tadelva SRL y otros s/amparo, 20/5/2014, consid. 5): “. . la la discriminación no suele manifestarse de forma abierta y claramente identificable; de allí que su prueba con frecuencia resulte compleja. Lo más habitual es que la discriminación sea una acción más presunta que patente, y difícil de demostrar ya que normalmente el motivo subyacente a la diferencia de trato está en la mente de su autor, y “la información y los archivos que podrían servir de elementos de prueba están, la mayor parte de las veces, en manos de la persona a la que se dirige el reproche de discriminación”, con cita de Pellicori, Fallos: 334:1387, considerando $7^{\circ}$.

${ }^{88}$ Sobre categorías sospechosas ver Gullco, Hernán, “El uso de las Categorías Sospechosas en el derecho argentino", en Alegre, Marcelo y Gargarella, Roberto (comps.), El Derecho a la igualdad, Buenos Aires, LexisNexis, 2007; Treacy Guillermo "Categorías sospechosas y control de constitucionalidad" en Revista Lecciones y Ensayos, Facultad de Derecho, Universidad de Buenos Aires, Nro. 89, 2011. 


\section{Consideraciones finales}

Los pasos propuestos por Timmer se perfilan como una metodología para trabajar los estereotipos. Después de todo no es del todo extraña, empalma en un tramo con el examen de igualdad y con la determinación de la intensidad de los escrutinios con los que hay que evaluar las razones que sostienen la clasificación y que no se pueden basar en estereotipos. Es probable que la metodología requiera mejoras. No lo dudo. El objetivo de este trabajo era ponerla a prueba en su potencial reconstructivo de una jurisprudencia que usa análisis de estereotipos pero que no explicita una metodología. Esperemos que esta metodología logre deliberaciones "suficientemente buenas" para provocar "reformas sociales que, aunque modestas, si fueran institucionalizadas, asegurarían que el siguiente turno de deliberaciones pudiera acercarse más a esa paridad participativa, ${ }^{89}$ mejorando así en claridad". ${ }^{90}$ Sin lugar a dudas, Sisnero y el colectivo mujeres de Salta tendrán que seguir actuando para que la implementación de la sentencia sea eficaz. ${ }^{91}$

A pesar de que la Corte IDH condenó a Chile por violación a la prohibición de discriminación por orientación sexual en el caso Atala, Karen Atala no recuperó en los hechos y en forma inmediata la tuición de sus niñas. ${ }^{92}$ Sin embargo, estas sentencias "hacen camino al andar" y nos posicionan con mejores

\footnotetext{
89 Según Nancy Fraser, para que la paridad participativa pueda darse tienen que cumplirse dos condiciones: una condición objetiva y otra intersubjetiva. De acuerdo con la condición objetiva, la "distribución de recursos materiales debe hacerse de manera que garantice la independencia y la "voz" de todos los participantes". De acuerdo con la condición intersubjetiva, "los patrones institucionalizados de valor cultural expresen el mismo respeto a todos los participantes y garanticen la igualdad de oportunidades para conseguir la estima social". Fraser, Nancy: lustitia Interrupta. Siglo de Hombres Editores/Universidad de los Andes, Bogotá, 1997.

90 Fraser, Nancy: Escalas de Justicia. Herder, Barcelona, 2008, 93.

91 V., por ejemplo, Corte de Justicia de la Provincia de Salta, Sisnero, Mirtha Graciela; Caliva, Lía Verónica c. Ahynarca S.A., Amparo, 23/11/2015, La Ley Online AR/JUR/51764/2015.

92 Entrevista a la Jueza Karen Atala, "Lesbofobia de Estado", en: Diario Página 12, 16/6/2017, accesible en: https://www.pagina12.com.ar/44360-lesbofobia-de-estado (última consulta 11/11/2017).
} 
herramientas para seguir demoliendo estereotipos de género, orientación sexual e identidad de género. Para las víctimas la sola sentencia en la que se reconocen los estereotipos y la discriminación tiene efectos reparadores. La Jueza Atala lo pone en las siguientes palabras, "el fallo dignificó a las madres lesbianas y padres gay. Nos reconoce como familia. Es la primera vez que en Chile te dicen que la familia es diversa." "Incluso, sirve como recurso para la solución de otros casos en el orden interno: Si lees los fallos a nivel nacional de mi caso, antes de llegar a la corte interamericana, los argumentos eran que las niñas en el contexto de una sociedad heterosexual podrían sufrir discriminación que les podría afectar su desarrollo. Las interpretaciones de la Corte Suprema [de Chile] hoy son muy distintas de lo que eran en 2004. Se ha internalizado que los Derechos Humanos son parte del derecho positivo. Se hacen esfuerzos para adecuar nuestra legislación decimonónica a los paradigmas actuales de DDHH." Por fin, fue también inspirador para resolver casos de este lado de la cordillera. "A una mujer detenida, que tenía un nene lactante, se le deniega arresto domiciliario diciéndole "tu compañera mujer está con el bebé", la jueza Atala interpreta, le están diciendo "hay dos madres, no hace falta que esté vos". El caso no quedó ahí. "La mujer detenida era la que amamantaba al niño", por eso la Cámara revocó la denegatoria y acogió su pedido sobre la base del caso Atala. ${ }^{93}$ Es urgente el uso cotidiano de la técnica del análisis de estereotipos. Esto debe ser complementado con otras medidas de acción positiva transformadoras de las estructuras que generan la desigualdad real para los colectivos identificados en el 75 inc. 23 y 17 de la Const. Nac. ${ }^{94}$

\footnotetext{
93 Entrevista a la Jueza Karen Atala, op. cit.

94 La reforma constitucional de 1994 receptó diagnósticos en varias partes de la constitución. Por ejemplo, en el inciso 23 del artículo 75 establece que no existe igualdad real de oportunidades para el pleno goce y ejercicio de los derechos reconocidos por la Constitución y por los IIDH en particular respecto de los niños, las mujeres, los ancianos y las personas con discapacidad. Para solucionar esta desigualdad que opera de hecho determina que el Congreso Nacional debe legislar y promover medidas de acción positiva. Dos conclusiones
} 
intermedias: primero, el carácter abstracto con que suelen ser reconocidos los derechos (piénsese por caso en el encabezado del art. 14 "todos los habitantes") es martillado por la desigualdad de hecho del art. 75 inc. 23 CN. Si bien todos los habitantes tienen derechos, los colectivos del art. 75 inc. 23 se encuentran en peores condiciones para gozarlos de forma efectiva. De ahí que hay que revisar todas las dogmáticas de los derechos desde la posición de los colectivos del artículo 75 inc. 23 CN para ver en qué medida estos desarrollos de los contenidos de los derechos los incluyen o los siguen excluyendo. Esto no es artificial, algo semejante está haciendo la Com. IDH, por ejemplo, en el Informe sobre Pueblos indígenas, comunidades afrodescendientes y recursos naturales: Protección de derechos humanos en el contexto de actividades de extracción, explotación y desarrollo, 2015, en la última parte advierte cómo afecta en especial a defensores y defensoras de derechos humanos, mujeres, niños y niñas, adultos mayores y personas con discapacidad. En suma, en el orden interno se requieren también dogmáticas críticas que tomen en cuenta la asimetría que establece el 75 inciso 23. 